\title{
Potential long non-coding RNAs to be considered as biomarkers or therapeutic targets in gastric cancer
}

\author{
Mohammadreza Hajjari ${ }^{1,2 *}$ and Atefeh Khoshnevisan ${ }^{1}$ \\ ${ }^{1}$ Department of Genetics, Shahid Chamran University of Ahvaz, Ahvaz, Iran \\ ${ }^{2}$ Department of Genetics, School of Biological Sciences, Tarbiat Modares University, Tehran, Iran \\ ${ }^{*}$ Correspondence: mohamad.hajari@gmail.com \\ Edited by: \\ Muller Fabbri, Childrens' Hospital Los Angeles and Keck School of Medicine University od Southern California, USA \\ Reviewed by: \\ Daisuke Ichikawa, Kyoto Prefectural University of Medicine, Japan
}

Keywords: long non-coding RNAs, expression level, gastric cancer, oncomine, biomarker

Long non-coding RNAs are attracting the attention of researchers in many fields. These RNAs are longer than 200 nucleotides and do not encode any protein. A subset of them is reported to be strongly correlated with poor patient prognosis, suggesting a potential role in cancer progression (Esteller, 2011).

Gastric cancer is one of the most common malignant tumors worldwide. Therefore, there is an urgent need to find genes which are helpful in the diagnosis, prognosis, and understanding of the molecular pathways of this cancer (Hajjari et al., 2013a).

Finding novel molecular biomarkers of malignancy has been always important for clinical management. Like proteins, mRNAs, and miRNAs, lncRNAs show potentials as novel biomarkers and therapeutic targets in different cancer types (Zhang et al., 2013). However, there are a few reports on studying the relationship between gastric cancer progression and lncRNAs. Some useful clues for further researches seem necessary for deciphering the potential role of IncRNAs in gastric cancer. In this report, we present and highlight some evidences about the potential role of lncRNAs in gastric cancer based on the data indicated in Microarray databases. The results may give novel perspectives for further researches on the role of lncRNAs in gastric carcinogenesis.

We used different databases including Oncomine, Gene Expression Atlas, Gene Expression Omnibus (GEO), and Array Express Databases to analyze the expression level of most recent cited and noted lncRNAs in studies on cancer progression (Niland et al., 2012; Zhang et al., 2013). The selected lncRNAs have been regarded as the most potential biomarkers in the studies on different cancer types (Zhang et al., 2013). The RNAs include H19, MALAT-1, HOTAIR, ANRIL, CRNDE, and MEG3. Some descriptions of these lncRNAs are presented below.

Oncomine cancer microarray database was used to mine the lncRNA expression profile data according to the established methodology (Rhodes et al., 2007). Four publicly available datasets [Chen Gastric (Chen et al., 2003), DErrico Gastric (D’Errico et al., 2009), Wang Gastric (Wang et al., 2012), and Cho Gastric (Cho et al., 2011)] were inquired for our analysis. By using Oncomine and other microarray expression data accessible from GEO, Gene expression Atlas, and Array Express database, we found some significant differences of expression level for the lncRNAs. The datasets and clinopathological data of each study are presented in Table 1.

Student's $t$-test was used for the differential expression analyses. Those which have significant differences (Fold change $>$ $1.5, P$-value $<0.01$ ) between gastric cancer and normal tissues are brought in Table 2.

\section{MALAT-1}

We found that the expression level of MALAT-1 is not significantly different between gastric cancer and normal tissues in the datasets. MALAT-1 was originally identified to be up-regulated in patients at the high risk of metastasis of non-small cell lung tumors (NSCLC). It seems that MALAT-1 functions in the regulation of alternate splicing by modulating the activity of SR proteins (Ji et al., 2003).
ANRIL

There are some reports indicating that ANRIL plays an important role in the repression of $\mathrm{P} 14^{\mathrm{ARF}}, \mathrm{P} 15^{\mathrm{INK} 4 \mathrm{~b}}$, and $\mathrm{P} 16^{\mathrm{INK} 4 \mathrm{a}}$. The proposed mechanism of ANRIL is an interaction with Polycomb complexes and silencing target genes. Although some relationships between the ANRIL gene and cancer progression have been reported (Yu et al., 2008), we could not find any significant differences of expression between gastric tumor and normal tissues in the datasets.

\section{CRNDE}

CRNDE has been identified as an lncRNA whose expression is highly elevated in some tumors. It seems that CRNDE is associated with a "stemness" signature in some cancer types (Ellis et al., 2012). For the expression of this IncRNA, we did not find any significant differences between gastric cancer and normal tissues in selected datasets.

\section{HOTAIR}

The datasets show that this lncRNA is upregulated in gastric adenocarcinoma compared with normal tissues. HOTAIR is an lncRNA that binds to the PRC2 complex and targets it at some genes involved in tumor suppression. Its up-regulation is reported in different cancer types (Gupta et al., 2010).

\section{H19}

There is a significant up-regulation in gastric adenocarcinoma tissues compared with normal ones in our results drawn from databases (Table 2). H19 is an lncRNA which is implicated as having both oncogenic and tumor suppression 
Table 1 | Different datasets and their clinicopathological data used in the current study.

\begin{tabular}{|c|c|c|}
\hline Dataset & Clinicopathological data (number of cases) & References \\
\hline \multicolumn{3}{|c|}{ ONCOMINE DATABASE } \\
\hline Chen gastric & $\begin{array}{l}\text { Normal tissues (29) } \\
\text { Diffuse gastric adenocarcinoma (13) } \\
\text { Gastric adenocarcinoma (15) } \\
\text { Gastric intestinal type adenocarcinoma (67) } \\
\text { Gastric mixed adenocarcinoma (8) }\end{array}$ & Chen et al., 2003 \\
\hline DErrico gastric & $\begin{array}{l}\text { Normal tissues (31) } \\
\text { Diffuse gastric adenocarcinoma (6) } \\
\text { Gastric adenocarcinoma (2) } \\
\text { Gastric intestinal type adenocarcinoma (26) } \\
\text { Gastric mixed adenocarcinoma (4) }\end{array}$ & D'Errico et al., 2009 \\
\hline Wang gastric & $\begin{array}{l}\text { Normal tissues(15) } \\
\text { Gastric cancer (12) }\end{array}$ & Wang et al., 2012 \\
\hline Cho gastric & $\begin{array}{l}\text { Normal tissues(19) } \\
\text { Gastric adenocarcinoma (65) } \\
\text { Gastrointestinal stromal tumor (6) }\end{array}$ & Cho et al., 2011 \\
\hline \multicolumn{3}{|c|}{ GENE ATLAS DATABASE } \\
\hline & $\begin{array}{l}\text { Normal tissues (31) } \\
\text { Gastric tumors (38) }\end{array}$ & D'Errico et al., 2009 \\
\hline \multicolumn{3}{|c|}{ ARRAY EXPRESS DATABASE } \\
\hline E-MTAB-1440 & $\begin{array}{l}\text { Normal mucosa(20) } \\
\text { Gastric adenocarcinoma(20) }\end{array}$ & Released in Database \\
\hline \multicolumn{3}{|c|}{ GEO DATABASE } \\
\hline GSE22804 & $\begin{array}{l}\text { Marginal non-malignant tissue (14) } \\
\text { Gastric adenocarcinoma (14) }\end{array}$ & Marimuthu et al., 2011 \\
\hline GSE27342 & $\begin{array}{l}\text { Normal tissues (80) } \\
\text { Gastric cancer (80) }\end{array}$ & Cui et al., 2011 \\
\hline
\end{tabular}

Table 2 | Significant difference (Fold change $>1.5, P$-value $<0.01$ ) of the expression level of IncRNAs between gastric cancer types and normal tissues.

\begin{tabular}{|c|c|c|c|c|}
\hline IncRNA & $\begin{array}{l}\text { Fold change/ } \\
\text { T statistics }\end{array}$ & $P$-value & $\begin{array}{l}\text { Category1 (down } \\
\text { regulated) }\end{array}$ & Category2 (up-regulated) \\
\hline \multicolumn{5}{|c|}{ ONCOMINE DATABASE } \\
\hline$H 19$ & $\begin{array}{l}4.396 \\
2.084 \\
3.117\end{array}$ & $\begin{array}{l}2.21 \mathrm{E}-11 \\
0.003 \\
1.16 \mathrm{E}-6\end{array}$ & $\begin{array}{l}\text { Normal } \\
\text { Normal } \\
\text { Normal }\end{array}$ & $\begin{array}{l}\text { Gastric adenocarcinoma } \\
\text { Diffuse gastric adenocarcinoma } \\
\text { Gastric intestinal type adenocarcinoma }\end{array}$ \\
\hline MEG3 & 1.572 & 0.003 & $\begin{array}{l}\text { Gastric mixed } \\
\text { adenocarcinoma }\end{array}$ & Normal \\
\hline \multicolumn{5}{|c|}{ GENE ATLAS DATABASE } \\
\hline HOTAIR & 3.2 & 0.008 & Normal & Gastric cancer \\
\hline$H 19$ & $\begin{array}{l}1.5 \\
3.84 \\
6.9\end{array}$ & $\begin{array}{l}2.17 \mathrm{E}-4 \\
0.0001 \\
0.0001\end{array}$ & $\begin{array}{l}\text { Normal } \\
\text { Normal mucosa } \\
\text { Marginal non-malignant } \\
\text { tissue }\end{array}$ & $\begin{array}{l}\text { Gastric cancer } \\
\text { Gastric adenocarcinoma } \\
\text { Gastric adenocarcinoma }\end{array}$ \\
\hline
\end{tabular}


properties. These two controversial roles of $\mathrm{H} 19$ may be attributed to the nature of $\mathrm{H} 19$ function or context in different tissues. Our results may support its oncogenic role in gastric carcinogenesis.

\section{MEG3}

MEG3 is an lncRNA which is identified as having an inhibitory role in tumor growth. This lncRNA is the first one proposed to have a tumor suppressor role (Zhang et al., 2003). By querying the databases, we found that the expression level of MEG3 is down-regulated in gastric adenocarcinoma compared with normal tissues.

Altogether, based on the results, it seems that some lncRNAs such as HOTAIR, H19, and MEG3 may potentially be suitable candidates for study in order to find some biomarkers or therapeutic targets. Hajjari et al. found a significant up-regulation of HOTAIR lncRNA in gastric adenocarcinoma tissues compared with normal ones by Real-time PCR (Hajjari et al., 2013b). Also, Yang et al. found that $H 19$ levels were increased in gastric cancer cells and tissues compared with normal controls (Yang et al., 2012). These studies provide supportive evidences concerning the important role of these two lncRNAs in gastric cancer progression.

The different expression of certain cancer type-specific lncRNAs can be exploited for the development of novel biomarkers as lncRNA expression (Gibb et al., 2011). Although there are some reports indicating the effect of downregulation of HOTAIR and H19 on cell proliferation and metastasis (Yang et al., 2012; Xu et al., 2013), we believe that these functional studies are worth being undertaken on more samples. Besides, understanding their biological roles in normal developments might provide some directions for using these enigmatic molecules as diagnostic or predictive biomarkers.

Our results, drawn from microarray databases, may help researchers to investigate the role of lncRNAs in gastric cancer progression. Large scale and follow-up studies are necessary to consider lncRNAs such as HOTAIR and H19 as potential biomarkers or therapeutic targets in this type of cancer.

\section{REFERENCES}

Chen, X., Leung, S. Y., Yuen, S. T., Chu, K. M., Ji, J., Li, R., et al. (2003). Variation in gene expression patterns in human gastric cancers. Mol. Biol. Cell 14, 3208-3215. doi: 10.1091/mbc.E02-12-0833

Cho, J. Y., Lim, J. Y., Cheong, J. H., Park, Y. Y., Yoon, S. L., Kim, S. M., et al. (2011). Gene expression signature-based prognostic risk score in gastric cancer. Clin. Cancer Res. 17, 1850-1857. doi: 10.1158/1078-0432.CCR-10-2180

Cui, J., Chen, Y., Chou, W. C., Sun, L., Chen, L., Suo, J., et al. (2011). An integrated transcriptomic and computational analysis for biomarker identification in gastric cancer.Nucleic Acids Res. 39, 1197-1207. doi: 10.1093/nar/gkq960

D’Errico, M., De Rinaldis, E., Blasi, M. F., Viti, V., Falchetti, M., Calcagnile, A., et al. (2009). Genome-wide expression profile of sporadic gastric cancers with microsatellite instability. Eur. J. Cancer 45, 461-469. doi: 10.1016/j.ejca.2008.10.032

Ellis, B. C., Molloy, P. L., and Graham, L. D. (2012). CRNDE: a long non-coding RNA involved in cancer, neurobiology, and development. Front. Genet. 3:270. doi: 10.3389/fgene.2012.00270

Esteller, M. (2011). Non-coding RNAs in human disease. Nat. Rev. Genet. 12, 861-874. doi: $10.1038 / \mathrm{nrg} 3074$

Gibb, E. A., Brown, C. J., and Lam, W. L. (2011). The functional role of long non-coding RNA in human carcinomas. Mol. Cancer 10, 38. doi: 10.1186/14764598-10-38

Gupta, R. A., Shah, N., Wang, K. C., Kim, J., Horlings, H. M., Wong, D. J., et al. (2010). Long non-coding RNA HOTAIR reprograms chromatin state to promote cancer metastasis. Nature 464, 1071-1076. doi: 10.1038/nature08975

Hajjari, M., Behmanesh, M., Sadeghizadeh, M., and Zeinoddini, M. (2013a). Junctional adhesion molecules 2 and 3 may potentially be involved in progression of gastric adenocarcinoma tumors. Med. Oncol. 30, 380. doi: 10.1007/s12032-0120380-z

Hajjari, M., Behmanesh, M., Sadeghizadeh, M., and Zeinoddini, M. (2013b). Up-regulation of HOTAIR long non-coding RNA in human gastric adenocarcinoma tissues. Med. Oncol. 30, 670. doi: 10.1007/s12032-013-0670-0

Ji, P., Diederichs, S., Wang, W., Böing, S., Metzger, R., Schneider, P. M., et al. (2003). MALAT-1, a novel noncoding RNA, and thymosin beta4 predict metastasis and survival in early-stage non-small cell lung cancer. Oncogene 22, 8031-8041. doi: 10.1038/sj.onc. 1206928

Marimuthu, A., Jacob, H. K. C., Jakharia, A., Subbannayya, Y., Keerthikumar, S., Kashyap, M.
K., et al. (2011). Gene expression profiling of gastric cancer. J. Proteom. Bioinform. 4, 74-82. doi: 10.4172/jpb. 1000170

Niland, C. N., Merry, C. R., and Khalil, A. M. (2012). Emerging roles for long non-coding RNAs in cancer and neurological disorders. Front. Genet. 3:25. doi: 10.3389/fgene.2012.00025

Rhodes, D. R., Kalyana-Sundaram, S., Mahavisno, V., Varambally, R., Yu, J., Briggs, B. B., et al. (2007). Oncomine 3.0: genes, pathways, and networks in a collection of 18,000 cancer gene expression profiles. Neoplasia 9, 166-180. doi: 10.1593/neo.07112

Wang, Q., Wen, Y. G., Li, D. P., Xia, J., Zhou, C. Z., Yan, D. W., et al. (2012). Upregulated INHBA expression is associated with poor survival in gastric cancer. Med. Oncol. 29, 77-83. doi: 10.1007/s12032010-9766-y

Xu, Z. Y., Yu, Q. M., Du, Y. A., Yang, L. T., Dong, R. Z., Huang, L., et al. (2013). Knockdown of long noncoding RNA HOTAIR suppresses tumor invasion and reverses epithelial-mesenchymal transition in gastric cancer. Int. J. Biol. Sci. 9, 587-597. doi: 10.7150/ijbs.6339

Yang, F., Bi, J., Xue, X., Zheng, L., Zhi, K., Hua, J., et al. (2012). Up-regulated long non-coding RNA H19 contributes to proliferation of gastric cancer cells. FEBS J. 279, 3159-3165. doi: 10.1111/j.17424658.2012.08694.x

Yu, W., Gius, D., Onyango, P., Muldoon-Jacobs, K., Karp, J., Feinberg, A. P., et al. (2008). Epigenetic silencing of tumour suppressor gene p15 by its antisense RNA. Nature 451, 202-206. doi: $10.1038 /$ nature 06468

Zhang, H., Chen, Z., Wang, X., Huang, Z., He, Z., and Chen, Y. (2013). Long non-coding RNA: a new player in cancer. J Hematol. Oncol. 6, 37. doi: 10.1186/1756-8722-6-37

Zhang, X., Zhou, Y., Mehta, K. R., Danila, D. C., Scolavino, S., Johnson, S. R., et al. (2003). A pituitary-derived MEG3 isoform functions as a growth suppressor in tumor cells. J. Clin. Endocrinol. Metab. 88, 5119-5126. doi: 10.1210/jc.2003-030222

Received: 12 September 2013; accepted: 01 October 2013; published online: 18 October 2013.

Citation: Hajjari $M$ and Khoshnevisan A (2013) Potential long non-coding RNAs to be considered as biomarkers or therapeutic targets in gastric cancer. Front. Genet. 4:210. doi: 10.3389/fgene.2013.00210 This article was submitted to Non-Coding RNA, a section of the journal Frontiers in Genetics.

Copyright (c) 2013 Hajjari and Khoshnevisan. This is an open-access article distributed under the terms of the Creative Commons Attribution License (CC BY). The use, distribution or reproduction in other forums is permitted, provided the original author(s) or licensor are credited and that the original publication in this journal is cited, in accordance with accepted academic practice. No use, distribution or reproduction is permitted which does not comply with these terms. 